\title{
Microflora of the selected water reservoirs in Swietokrzyskie Voivodship*
}

\author{
Wioletta Adamus-Bialek ${ }^{\circledR}$, Karolina Karwacka² and Lukasz Bak ${ }^{3}$ \\ 'Department of Environment Protection and Modelling, Jan Kochanowski University, Kielce, Poland; ${ }^{2 B i o t e c h n o l o g y ~ A c a d e m i c ~ C i r c l e ~-~ M i k r o b y ; ~}$ \\ Department of Microbiology, Institute of Biology, Jan Kochanowski University, Kielce, Poland; ${ }^{3}$ Department of Geotechnics and Water Engineer- \\ ing, University of Technology, Kielce, Poland
}

\begin{abstract}
One of the important environmental issues is the quality of surface waters in the world. Poland belongs to countries with a low quality of the inland waters. The sanitary condition of the five water reservoirs of south-east Poland was analyzed. Water and sediment samples were incubated on the selective and/or differential media. High concentrations of many common and pathogenic microbial indicators were shown in those samples. Those reservoirs are used by people, especially during summer. Because of the high epidemiological risk, detailed analysis of all inland waters should be performed routinely.
\end{abstract}

Key words: epidemiological analysis, water, bottom sediment, water reservoirs

Received: 08 November, 2013; revised: 27 November, 2013; accepted: 16 December, 2013; available on-line: 30 December, 2013

\section{INTRODUCTION}

Many organizations, both worldwide (e.g. Centre for Disease Prevention and Control, European Parliament, World Health Organization) and in Poland (e.g. Ministry of Health and Ministry of Environment, The State Sanitary Inspectorate) get engaged in the protection and control of water resources. Despite this, with current trends, the world will miss the sanitation target by more than half a billion people. Every year, hazardous water, coupled with lack of basic sanitation, kills at least 1.6 million children under the age of five years (Joint Monitoring Programme for Water Supply and Sanitation, 2006). Poland is among countries with inadequate water resources which are characterized by significant seasonal variability and an unequal territorial distribution (Central Statistical Office, 2013). The capacity of storage reservoirs in Poland is small, able to hold only $6 \%$ of the yearly effluent of water. It doesn't provide adequate safeguard against periodic deficits of water. Out of 139 lakes subjected to monitoring in 2010, 5 lakes (4\% of the total lake waters) had very good ecological water status (I class quality). Lakes with moderate ecological water status (III class quality) constituted the largest group (81 lakes). They accounted for $50 \%$ of the total volume of monitored lake waters. The lakes with bad ecological water status (V class quality) represented $9 \%$ of the total number of the lakes. Additionally, wastewater is still discharged into surface water and grounds in some cities and countries. In 2012, wastewater treatment plants served only 69\% of the population ( $92 \%$ in urban areas and $33 \%$ in rural areas, where about $39 \%$ of the population lives). In 2012, five towns were not served by wastewater treat- ment plants. Approximately $15 \%$ of plants discharging wastewater right into the water or into the ground didn't possess wastewater treatment plants. Only 55\% of the towns and $26 \%$ of the rural municipalities were served by modern wastewater treatment plants with increased biogene removal (disposal). In these plants, $82 \%$ of the wastewater was discharged through urban and rural sewage systems (Central Statistical Office, 2013).

The economic and environmental condition of the country has a significant impact on water

quality (Mazari-Hiriart et al., 2008; Hlavsa et al., 2011). Microbiological water quality is evaluated based on the number of particular microorganisms, especially Escherichia coli and Enterococcus sp, identified by standardized methods (Toranzos \& McFeters, 1998; Bartram \& Rees, 2000; Jones et al., 2002; Pickup et al., 2003). Unfortunately, many more pathogenic bacterial species are often identified in water, for example Salmonella spp., Shigella sp., Clostridium perfringens, Listeria monocytogenes, Vibrio cholera and others (Mazari-Hiriart et al., 2001; Le Dantec et al., 2002; Smylla et al., 2003; Hlavsa et al., 2011; ECDC, 2012).

The aim of this study was to analyze microbiologically the water and bottom sediments of selected water reservoirs in Swietokrzyskie Province in winter and spring 2013. Water and sediment samples were tested for the presence of Escherichia coli, Enterocuccus faecalis, Salmonella spp., Shigella sp., Clostridium perfrigens and mesophilic and psychrophilic bacteria.

\section{MATERIALS AND METHODS}

Study sites and sample collection. The study sites covered 5 water reservoirs (Kaniow, Lubianka, Suchedniow, Umer, Wilkow) located in the Swietokrzyskie Voivodship in the south-east Poland (Table 1). The samples of water and sediments were taken from three points (inlet, center, outlet) of the reservoirs during winter (05.03.2013) and spring (27.05.2013) into sterile bottles. The sediment samples were derived from $0.5-4 \mathrm{~m}$ depth of the bottom by Sampler (Becker). Samples were taken from the centre of the sampler core. The water samples were derived from approx 1 depth of water ta-

e-mail: aloiv2002@wp.pl; wioletta.adamus-bialek@ujk.edu.pl *Presented at the 3-rd Workshop on Microbiology "MIKROBIOT 2013" in Łódź, Poland.

Abbreviations: C. perfringens, Clostridium perfringens; cfu, colony forming units; E. coli, Escherichia coli; E. faecalis, Enterococcus faecalis; sp., spp., species; 
ble of the reservoir. The $\mathrm{pH}$ of the samples was 6.9-7.6 and the temperature of the samples was $2.5-5.1^{\circ} \mathrm{C}$ in the winter and $12.8-17.6^{\circ} \mathrm{C}$ in the spring. A total of 18 water samples and 14 sediment samples in the winter, 14 water samples and 14 sediment samples in the spring were taken into sterile bottles.

Bacterial identification. Samples were diluted serially $\left(10^{0}, 10^{-1}, 10^{-2}, 10^{-3}, 10^{-4}\right)$ and plated on growth and selective chromogenic media: Yeast Extract (Biocorp, ISO 6222) for the total number of mesophilic and psychrophilic bacteria; TSC Lab-Agar (Biocorp, ISO 7937, ISO 15213) for Clostridium perfringens; Salmonella — Shigella Lab-Agar (Biocorp, ISO 10273) for Salmonella spp., Shigella sp. and E. coli; Endo (Biocorp) for E. coli; Bile Esculin Azide Lab-Agar (Biocorp, ISO 7899-2) for E. faecalis; E. coli Chromogenic Medium (Biocorp) for E. coli. The cultures were carried out according to the media manufacturer's instructions. Analyses were carried out according to the Polish Committee of Standardization Norms PN-EN ISO 6222. Samples were plated by spread plate method and incubated at $37^{\circ} \mathrm{C}$ (mesophilic bacteria) and $22^{\circ} \mathrm{C}$ (psychrophilic bacteria) for $24-48 \mathrm{~h}$. The isolation of $C$. perfringens was carried out in anaerobic conditions. Grown and characterized bacterial colonies were counted, classified into various types and Gram stained to observe them under the light microscope. The number of bacteria was counted based on the cfu number (colony forming units) that appeared on the media.

\section{RESULTS AND DISCUSSION}

Our research of selected water reservoirs analyzed the presence of different bacterial indicators of the water and the bottom sediment contamination. Samples were taken from five water reservoirs located in Swietokrzyskie Voivodship in the south-east Poland. The reservoirs were characterized based on the features which could influence their microbiological condition: volume $\left(\mathrm{km}^{3}\right)$, mean depth $(\mathrm{m})$, water surface (ha), average $\mathrm{pH}$ and temperature, the characteristics of the bottom and the catchment area (Table 1). The reservoirs were rather similar, with exception of the bottom of the Lubianka reservoir (organic soil) and volume of the Kaniow reservoir (the smallest reservoir). Based on preliminary analysis, there was no simple correlation between the reservoir and the presence of the bacteria. There are many factors that can affect individually or simultaneously the quality of the water and sediment. The study involved analysis of the presence of total coliforms and Escherichia coli, Salmonella spp., Shigella sp., Enterococcus faecalis, Clostridium perfringens. Marking the total number of mesophilic and psychrophilic bacteria was used as a further indicator element of organic matter contamination and as a source of microorganisms with potentially high adaptive properties (Nedwell, 1999). It can be confirmed by an easy method of growing bacteria on the medium at $22^{\circ} \mathrm{C}$ or $37^{\circ} \mathrm{C}$, after their isolation from the cold water (about $4^{\circ} \mathrm{C}$ ). The total number of bacteria varied widely, depending on a reservoir, a place the sample was taken and type of the analyzed sample (Table 2). Psychrophilic bacteria and bacteria from the sediment samples were the most numerous. The highest number of the bacteria was identified in Wilkow. Cultivated bacteria showed a few different types of colonies. 10 types of colonies from the water and 15 types of colonies from the sediment were identified. Usually Gram positive bacilli with spores were

Table 1. Characteristics of the water reservoirs

\begin{tabular}{|c|c|c|c|c|c|c|c|c|c|}
\hline \multirow{2}{*}{$\begin{array}{l}\text { Reservoirs. } \\
\text { (established) }\end{array}$} & \multirow{2}{*}{$\begin{array}{l}\text { Spillway. weir } \\
\text { Coordinates }\end{array}$} & \multirow{2}{*}{$\begin{array}{l}\text { Volume } \\
\left(\mathrm{km}^{3}\right)\end{array}$} & \multirow{2}{*}{$\begin{array}{l}\text { Mean } \\
\text { Depth } \\
(\mathrm{m})\end{array}$} & \multirow{2}{*}{$\begin{array}{l}\text { Water } \\
\text { surface } \\
\text { (ha) }\end{array}$} & \multirow{2}{*}{$\mathrm{pH}$} & \multicolumn{2}{|c|}{ Average $\mathrm{T}\left({ }^{\circ} \mathrm{C}\right)$} & \multirow{2}{*}{$\begin{array}{l}\text { Bottom - Con- } \\
\text { tents of organic } \\
\text { matter }(\%)\end{array}$} & \multirow{2}{*}{$\begin{array}{l}\text { Catchment } \\
\text { area }\left[\mathrm{km}^{2}\right]\end{array}$} \\
\hline & & & & & & winter & spring & & \\
\hline $\begin{array}{l}\text { Kaniow } \\
\text { (1986) }\end{array}$ & $\begin{array}{l}\text { N 50॰59'9.71" } \\
\text { E 20॰40'15.15" }\end{array}$ & 40 & 1.9 & 2.12 & $6.92-7.45$ & $1-1.5$ & $12.4-15.9$ & $\begin{array}{l}2.4-7.1 \\
\text { sand. silty sand }\end{array}$ & $\begin{array}{l}7.65 \\
\text { Forests (over } \\
80 \%) . \text { mead- } \\
\text { ows (18.5\%). } \\
\text { arable land } \\
(0.4 \%) \text {. built- } \\
\text { up area }(0.7 \%)\end{array}$ \\
\hline $\begin{array}{l}\text { Lubianka } \\
\text { (1984) }\end{array}$ & $\begin{array}{l}\text { N 51०1'25.43" } \\
\text { E 21०3'11.32" }\end{array}$ & 927 & 3.1 & 30 & $6.88-7.88$ & $1-1.25$ & 19.8-20.8 & $\begin{array}{l}24.1-26.1 \\
\text { organic soil }\end{array}$ & $\begin{array}{l}37.60 \\
\text { forests (over } \\
92 \%) . \text { built-up } \\
\text { area. green } \\
\text { area }(8 \%)\end{array}$ \\
\hline $\begin{array}{l}\text { Suchedniow } \\
\text { (1974) }\end{array}$ & $\begin{array}{l}\text { N 512'57.07" } \\
\text { E 20॰50'26.19" }\end{array}$ & 303 & 1.42 & 21.4 & $7.2-7.79$ & $1.15-1.98$ & $16.1-17.5$ & $\begin{array}{l}9.0-18.9 \\
\text { silty loam. clayey } \\
\text { loam }\end{array}$ & $\begin{array}{l}83 \\
\text { Forests (over } \\
45 \%) . \text { Mead- } \\
\text { ows (32\%). } \\
\text { arable land } \\
\text { (18\%). built-up } \\
\text { area (5\%) }\end{array}$ \\
\hline $\begin{array}{l}\text { Umer } \\
(2004)\end{array}$ & $\begin{array}{l}\text { N } 50^{\circ} 59^{\prime} 6.65^{\prime \prime} \\
\text { E } 20^{\circ} 35^{\prime} 20.58^{\prime \prime}\end{array}$ & 196 & 1.65 & 11.9 & $7.57-9.13$ & $1.5-1.56$ & $20.5-27.5$ & $\begin{array}{l}2.2-7.3 \\
\text { sandy silt. clayey } \\
\text { loam }\end{array}$ & $\begin{array}{l}60.5 \\
\text { Forests (about } \\
50 \%) . \text { me- } \\
\text { adows and } \\
\text { arable land } \\
(46 \%) . \text { built-up } \\
\text { area (4\%) }\end{array}$ \\
\hline $\begin{array}{l}\text { Wilkow } \\
\text { (2004) }\end{array}$ & $\begin{array}{l}\text { N 50॰55'5.34" } \\
\text { E 20॰50'40.18" }\end{array}$ & 163 & 1.57 & 10.4 & $7.07-8.41$ & $1-1.23$ & $23.5-24.4$ & $\begin{array}{l}5.6-7.6 \\
\text { sandy silt. clayey } \\
\text { loam }\end{array}$ & $\begin{array}{l}21 \\
\text { Forests (44\%). } \\
\text { Meadows. } \\
\text { arable land } \\
\text { (35\%). built-up } \\
\text { area (3\%) }\end{array}$ \\
\hline
\end{tabular}


Table 2. The total number of mesophilic and psychrophilic bacteria present in the water and bottom sediment samples of the water reservoirs analyzed by the number of colonies

(cfu/ml of water samples; cfu/g of sediment samples) grown on the Yeast Extract medium; S.D. — standard deviation.

\begin{tabular}{|c|c|c|c|c|c|c|}
\hline \multirow{2}{*}{ Samples } & \multirow{2}{*}{ Season } & \multirow{2}{*}{ Reservoir } & \multicolumn{2}{|c|}{ Mesophile } & \multicolumn{2}{|c|}{ Psychrophile } \\
\hline & & & average & S.D. & average & S.D. \\
\hline \multirow{10}{*}{ 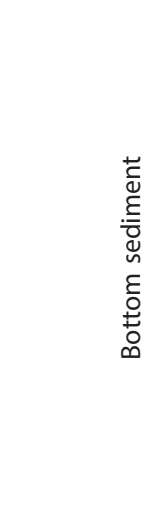 } & \multirow{5}{*}{ winter } & Kaniow & 10400 & 3245 & 49333 & 28361 \\
\hline & & Lubianka & 13617 & 9917 & 74733 & 94762 \\
\hline & & Suchedniow & 33283 & 20106 & 60667 & 46188 \\
\hline & & Umer & 15867 & 10207 & 48000 & 47149 \\
\hline & & Wilkow & 79000 & 15556 & 121500 & 37477 \\
\hline & \multirow{5}{*}{ spring } & Kaniow & 31511 & 18577 & 181600 & 178530 \\
\hline & & Lubianka & 231233 & 298426 & 102869 & 29681 \\
\hline & & Suchedniow & 182417 & 222291 & 26250 & 1768 \\
\hline & & Umer & 11308 & 6999 & 40842 & 17378 \\
\hline & & Wilkow & 79867 & 23697 & 246667 & 107066 \\
\hline \multirow{10}{*}{$\frac{ \pm}{\stackrel{ \pm}{ \pm}}$} & \multirow{5}{*}{ winter } & Kaniow & 20 & 18 & 1599 & 726 \\
\hline & & Lubianka & 433 & 504 & 14303 & 18735 \\
\hline & & Suchedniow & 227 & 103 & 1328 & 451 \\
\hline & & Umer & 304 & 276 & 6110 & 5200 \\
\hline & & Wilkow & 600 & 471 & 17283 & 17488 \\
\hline & \multirow[t]{5}{*}{ spring } & Kaniow & 582 & 305 & 19553 & 11456 \\
\hline & & Lubianka & 195 & 48 & 335 & 317 \\
\hline & & Suchedniow & 73 & 4 & 285 & 78 \\
\hline & & Umer & 105 & 35 & 137 & 42 \\
\hline & & Wilkow & 417 & 292 & 1199 & 686 \\
\hline
\end{tabular}

detected, most often in the sediment, during winter. This seems to be normal because of the prevailing climatic conditions (low temperature) and the environment. High turbidity of the water samples indicated mixing with the upper parties of the bottom sediment. This can have an important influence on the water contamination by the bacteria from the sediment.

The samples were taken only once or twice from three different points of each reservoir for one season. Therefore, results gave high standard deviations. There should be more samples from each point, but these results also showed large variation in the number of different bacterial species in the water reservoir. Despite a small number of the samples, a large number of pathogenic bacteria was often identified in a small volume of the samples (Table 2). Characteristic colonies of E. coli, Shigella sp. and Salmonella spp. were identified on the specific media. These results were obtained for each reservoir, in the water and/or in the sediment. A difference between cfu numbers of E. coli and coliforms (Table 3) can indicate various sensitivity of the media (E. coli chromogenic medium, Endo, SS) or different number of bacteria in the $100 \mu \mathrm{l}$ of the sample (Gonzalez et al., 1992). Shigella sp. and Salmonella spp. strains were especially numerously represented, with exception of the Kaniow reservoir. E. faecalis were very rarely identified. High concentration of this bacteria was identified only once, in the bottom sediment of Lubianka, during spring (Table 3). Anaerobic sporulating bacilli of $C$. perfringens in general were not identified. Also, the presence of the microbial indicators was not detected in the bottom sediment in the winter. However, this number has increased dramatically in the spring. In addition, many more bacteria were identified in the sediments in comparison to the water of the reservoirs. The total number of the identified indicators in the bottom sediment of all reservoirs (557 cfu) was approx 3 times higher than in the water (168 cfu), in the spring. The results can be explained by the specific conditions of the reservoirs (Table 1). A large number of bacteria, especially in the sediments could be caused by groundwater flow into the reservoirs during fertilization of the fields. The bottom sediment of the Lubianka reservoir is identified as organic soil which can have an important influence on the high concentration of bacteria. The Kaniow reservoir was the purest. It is situated on a slight elevation relative to the surrounding farmlands. This may explain the lowest concentration of the intestinal bacteria in the studied samples.

Sanitary water analysis according to current microbiological standards in Poland and Europe involves the same biological indicators, but detection is in larger volume samples (Bartram \& Rees, 2000; Pickup et al., 2003; Regulation of the Minister of Health, 2010; Hlavsa et al., 2011). Recreational water reservoirs cannot contain more than $1000 \mathrm{cfu}$ of E. coli in $100 \mathrm{ml}$ of water, more than $400 \mathrm{cfu}$ of Enterocuccus sp in $100 \mathrm{ml}$ and any Salmonella spp. bacteria in $1000 \mathrm{ml}$ of water (Smylla et al., 2003; Regulation of the Minister of Health, 2010). This study presents the bacterial number of cfu in $1 \mathrm{ml}$. It should be noted that based on those standards, the total ac- 
Table 3 Presence of the microbiological indicators in the water and bottom sediment samples of the water reservoirs analyzed by the number of colonies

(cfu/ml of water sam ples; cfu/g of sediment samples) grown in different media; - not tested, 0 - not identified, S.D. — standard deviation.

\begin{tabular}{|c|c|c|c|c|c|c|c|c|c|c|c|c|c|c|c|c|}
\hline \multirow{3}{*}{$\begin{array}{l}\text { Sam- } \\
\text { ple }\end{array}$} & \multirow{3}{*}{ season } & \multirow{3}{*}{ Reservoir } & \multirow{2}{*}{\multicolumn{2}{|c|}{$\begin{array}{l}\text { E. coli } \\
\text { (Endo) }\end{array}$}} & \multirow{2}{*}{\multicolumn{2}{|c|}{$\begin{array}{l}\text { E. coli } \\
\text { (SS) }\end{array}$}} & \multirow{2}{*}{\multicolumn{4}{|c|}{$\begin{array}{l}\text { E. coli coliform } \\
\text { (E. coli chromogenic) }\end{array}$}} & \multirow{2}{*}{\multicolumn{2}{|c|}{$\begin{array}{l}\text { Shigella sp. } \\
\text { (SS) }\end{array}$}} & \multirow{2}{*}{\multicolumn{2}{|c|}{$\begin{array}{l}\text { Salmonella } \\
\text { spp. } \\
\text { (SS) }\end{array}$}} & \multirow{2}{*}{\multicolumn{2}{|c|}{$\begin{array}{l}\text { E. faecalis } \\
\text { (Bile esculin) }\end{array}$}} \\
\hline & & & & & & & & & & & & & & & & \\
\hline & & & $\begin{array}{l}\text { Ave- } \\
\text { rage }\end{array}$ & S.D. & $\begin{array}{l}\text { Ave- } \\
\text { rage }\end{array}$ & S.D. & $\begin{array}{l}\text { Ave- } \\
\text { rage }\end{array}$ & S.D. & $\begin{array}{l}\text { Ave- } \\
\text { rage }\end{array}$ & S.D. & $\begin{array}{l}\text { Ave- } \\
\text { rage }\end{array}$ & S.D. & $\begin{array}{l}\text { Ave- } \\
\text { rage }\end{array}$ & S.D. & $\begin{array}{l}\text { Ave- } \\
\text { rage }\end{array}$ & S.D. \\
\hline \multirow{6}{*}{ 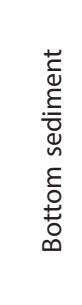 } & winter & no growth & & & & & & & & & & & & & & \\
\hline & \multirow{5}{*}{ spring } & Kaniow & 8 & 11 & 3 & 4 & 0 & 0 & 3 & 4 & 4 & 3 & 1 & 2 & 1 & 1 \\
\hline & & Lubianka & 16 & 13 & 2 & 1 & 0 & 0 & 56 & 51 & 108 & 67 & 1 & 1 & 56 & 29 \\
\hline & & Suchedniow & 0 & 0 & 3 & 3 & 0 & 0 & 3 & 4 & 25 & 25 & 0 & 0 & 1 & 1 \\
\hline & & Umer & 3 & 4 & 9 & 3 & 0 & 0 & 8 & 7 & 20 & 8 & 0 & 0 & 0 & 1 \\
\hline & & Wilkow & 3 & 3 & 2 & 2 & 0 & 0 & 29 & 21 & 57 & 59 & 1 & 1 & 3 & 3 \\
\hline \multirow{10}{*}{$\frac{\grave{d}}{\frac{ \pm}{3}}$} & \multirow{5}{*}{ winter } & Kaniow & 0 & 0 & 0 & 0 & - & - & - & - & 0 & 0 & 1 & 1 & 0 & 1 \\
\hline & & Lubianka & 3 & 4 & 0 & 0 & - & - & - & - & 2 & 3 & 10 & 10 & 0 & 0 \\
\hline & & Suchedniow & 0 & 0 & 0 & 1 & - & - & - & - & 0 & 1 & 0 & 1 & 0 & 1 \\
\hline & & Umer & 4 & 8 & 17 & 35 & - & - & - & - & 10 & 8 & 32 & 56 & 0 & 0 \\
\hline & & Wilkow & 1 & 1 & 1 & 1 & - & - & - & - & 0 & 0 & 61 & 53 & 0 & 0 \\
\hline & \multirow{5}{*}{ spring } & Kaniow & 0 & 0 & 0 & 0 & 2 & 2 & 0 & 0 & 0 & 0 & 0 & 0 & 1 & 1 \\
\hline & & Lubianka & 0 & 0 & 0 & 0 & 12 & 15 & 2 & 1 & 1 & 1 & 2 & 2 & 0 & 0 \\
\hline & & Suchedniow & 0 & 0 & 0 & 0 & 6 & 6 & 1 & 1 & 1 & 0 & 3 & 1 & 1 & 1 \\
\hline & & Umer & 0 & 0 & 0 & 0 & 6 & 2 & 1 & 1 & 2 & 2 & 1 & 1 & 0 & 1 \\
\hline & & Wilkow & 0 & 0 & 0 & 0 & 39 & 34 & 8 & 9 & 18 & 9 & 2 & 2 & 0 & 1 \\
\hline
\end{tabular}

ceptable concentration of those bacteria was exceeded in each of the analyzed reservoirs. All tested reservoirs were permitted for water activities in the summer, when the bacteria have better conditions to survive in this environment. In addition, municipalities are not required to test the bathing reservoirs as often as reservoirs classified as recreational by the European Union. This situation poses a serious threat to human health.

Rivers and reservoirs have been used for years as receivers of the wastewaters (Smylla et al., 2003; MazariHiriart et al., 2008; Central Statistical Office, 2013). This led to their degradation. Additionally, such contaminants pose epidemiological dangers and disrupt the natural biological balance (Langergraber \& Muellegger, 2005). The presence of the total coliforms or E. coli strains in the water may involve a lot of the intestinal and extraintestinal pathotypes of E. coli strains (Jones et al., 2002; ECDC, 2012). For example, the reported rates of human cases of VTEC (verotoxin-producing E. coli) infections have followed a significantly increasing trend in the fouryear period in the European Union (EU) and European Economic Area (EEA) countries since 2006. In 2010, 230 cases of haemolytic-uraemic syndrome were reported. Infection with vero/shiga toxin-producing Escherichia coli (VTEC/STEC) causes acute diarrhea, which may be bloody, and is often accompanied by mild fever and vomiting. The infection, also by uropathogenic (UPEC), enterohemorrhagic (EHEC) E. coli strains and others strains may lead to potentially fatal haemolytic-uraemic syndrome (HUS), affecting renal function and requiring hospital care (ECDC, 2012).
The next very important human pathogens are Salmonella spp. and Shigella sp. (Smylla et al., 2003). A high concentration of these bacteria in almost each of the reservoirs was detected in this study. In 2010, a total of 102323 confirmed salmonellosis cases were reported by 29 EU/EEA countries. Multinational Salmonella outbreaks underline the need to continuously strengthen coordinated investigations and control measures across the Member States, at the European level, and between human, veterinary and food safety organizations and networks. It is necessary to rapidly detect dispersed multinational strains as well as to investigate if and how the diverse Salmonella strains found in Member States (and world-wide) are related. Salmonella Paratyphi A was the most commonly identified serotype in cases of paratyphoid fever. These cases were in majority imported from India and Pakistan and constituted $84 \%$. These systemic bacterial diseases are caused by infection with Salmonella enterica serovars Typhi, Paratyphi A, Paratyphi B and Paratyphi C. Humans can be short- or long-term carriers of these bacteria; transmission is by fecal-oral route, through person-to-person contact, or contaminated water or food. Shigellosis infections may cause serious illness and death, and outbreaks appear. Humans are the only significant reservoir. Transmission occurs by the fecal-oral route, either through person-to-person contact, or through contaminated food or water. In 2010, 7312 confirmed shigellosis cases were reported in $28 \mathrm{EU} /$ EEA countries. Shigellosis remains a rather uncommon infection and the number of cases has remained stable (ECDC, 2012). 
Microbiological analysis of water is an essential part of environmental monitoring (Toranzos \& McFeters, 1998; Mazari-Hiriart et al., 2008; Sasikaran et al., 2012). Such studies allow tocontrol the condition of homeostasis in nature. It is also important in studies of biodiversity (Langergraber \& Muellegger, 2005). Periodical analysis of water is used to determine the typical indicators of microbial contamination of water. In the identification of environmental bacterial species, metagenomic methods are increasingly used. However, traditional microbiological methods allow for quick characterization of the cosmopolitan microorganisms (Gonzalez et al., 1992; Bartram \& Rees, 2000). Further correlations of chemo-physical, geographical and microbiological properties of the examined reservoirs permit for a wider determination of reciprocal dependencies of the mentioned components in a given environment (Sasikaran et al., 2012).

\section{Acknowledgements}

These studies were carried out within the project $\mathrm{N}$ N305 299040 financed by the National Centre of Science, contract number 2990/B/P01/2011/40.

\section{REFERENCES}

Bartram J, Rees G (2000) Monitoring Bathing Waters - A Practical Guide to the Design and Implementation of Assessments and Monitoring Programmes. WHO ISBN 0-419-24390-1.

Central Statistical Office (2013) Concise Statistical Yearbook of Poland, Ministry of National Education, Warszawa, Poland, ISSN 1640-3630 Publication available on the Internet - www.stat.gov.pl.

European Centre for Disease Prevention and Control. (2012) Annual Epidemiological Report Reporting on 2010 surveillance data and 2011 epidemic intelligence data. ECDC Stockholm.

Gonzalez J, Iriberri J, Egea L, Barcina I (1992) Characterization of culturabity, protistan grazing, and death of enteric bacteria in aquatic ecosystem. Applied and Environmental Microbiology 58: 998-1004.
Hlavsa MC, Roberts VA, Anderson AR, Hill VR, Kahler AM, Orr M, Garrison LE, Hicks LA, Newton A, Hilborn ED, Wade TJ, Beach MJ, Yoder JS (2011) Centers for Disease Control and Prevention. Surveillance for Waterborne Disease. Outbreaks and Other Health Events Associated with Recreational Water United States 20072008. MMWR Vol. 60: No. 12

Joint Monitoring Programme for Water Supply and Sanitation. II World Health Organization. III.UNICEF (2006) Meeting the MDG drinking water and sanitation target: the urban and rural challenge of the decade. WHO/UNICEF Geneva ISBN 9241563257.

Jones T, Gill CO, McMullen LM (2002) The behavior of log phase Escherichia coli at temperatures below the minimum for sustained growth. Food Microbiology 19: 83-90.

Langergraber G, Muellegger E (2005) Ecological Sanitation - a way to solve global sanitation problems? Evironmental International 31: 433-444.

Le Dantec C., Duguet JP, Montiel A, Dumoutier N, Dubrou S, Vincent V (2002) Occurence of Mycobacteria in Water Treatment lines and in Water Distribution Systems. Appl Environm Microbiol 68/11: 5318-5325.

Mazari-Hiriart M, Ponce-de-León S, López-Vidal Y, Islas-Macías P, Amieva-Fernández RI, Quiñones-Falconi F (2008) Microbiological implications of periurban agriculture and water reuse in Mexico City. PLOS ONE 3: e2305.

Nedwell DB (1999) Effect of low temperature on microbial growth: lowered affinity for substrates limits growth at low temperature. FEMS Microbiology Ecology 30: 101-111.

Pickup RW, Rhodes G, Hermon-Taylor J (2003) Monitoring bacterial pathogens in the environment: advantages of multilayered approach. Current Opinion in Biotechnology 14: 319-325.

Regulation of the Minister of Health on April 8, 2010 on the supervision over the quality of bathing water and the site used for bathing. Official Gazette No. 86.

Sasikaran S, Sritharan K, Balakumar S, Arasaratnam V (2012) Physical, chemical and microbial analysis of bottled drinking water. Ceylon Medical Journal 57: 111-116.

Smylla A, Piotrowska-Seget Z, Tyflewska A (2003) Pathogenic bacteria hazard in surface waters. AUMC Limnological Papers Torun 110: 159-169.

Toranzos GA, McFeters G (1998) Detection of indicator microorganisms in environmental freshwaters and drinking waters. in: Manual of Environmental Microbiology. Hurst C.J., Knudsen GR,Walter MV(eds) ASM Press, Washington. 